\title{
Consecutive wildfires affect stream biota in cold- and warmwater dryland river networks
}

\author{
James E. Whitney ${ }^{1,3}$, Keith B. Gido ${ }^{1,4}$, Tyler J. Pilger ${ }^{2,5}$, David L. Propst ${ }^{2,6}$, and Thomas F. Turner ${ }^{2,7}$ \\ ${ }^{1}$ Divison of Biology, Kansas State University, Manhattan, Kansas 66506 USA \\ ${ }^{2}$ Department of Biology and Museum of Southwestern Biology, University of New Mexico, Albuquerque, New Mexico 87131 USA
}

\begin{abstract}
Climate change and fire suppression have altered fire regimes globally, leading to larger, more frequent, and more severe wildfires. Responses of coldwater stream biota to single wildfires are well studied, but measured responses to consecutive wildfires in warmwater systems that often include mixed assemblages of native and nonnative taxa are lacking. We quantified changes in physical habitat, resource availability, and biomass of cold- and warmwater oligochaetes, insects, crayfish, fishes, and tadpoles following consecutive megafires (covering $>100 \mathrm{~km}^{2}$ ) in the upper Gila River, New Mexico, USA. We were particularly interested in comparing responses of native and nonnative fishes that might have evolved under different disturbance regimes. Changes in habitat and resource availability were related to cumulative fire effects, fire size, and postfire precipitation. The $2^{\text {nd }}$ of 2 consecutive wildfires in the basin was larger and, coupled with moderate postfire discharge, resulted in increased siltation and decreased algal biomass. Several insect taxa responded to these fires with reduced biomass, whereas oligochaete biomass was unaffected. Biomass of 6 of 7 native fish species decreased after the fires, and decreases were associated with site proximity to fire. Nonnative fish decreases after fire were most pronounced for coldwater salmonids, and warmwater nonnative fishes exhibited limited responses. All crayfish and tadpoles collected were nonnative and were unresponsive to fire disturbance. More pronounced responses of native insects and fishes to fires indicate that increasing fire size and frequency threatens the persistence of native fauna and suggests that management activities promoting ecosystem resilience might help ameliorate wildfire effects.

Key words: mega-fire, native fish, invasive species, macroinvertebrates, warmwater stream, disturbance, ash flows
\end{abstract}

Wildfires are natural agents of ecological change in rivers draining forested biomes across the globe (Bowman et al. 2009, Pausas and Keeley 2009) and are important in maintaining their physical and biological heterogeneity (Covington et al. 1994, Hessburg and Agee 2003, Hurteau et al. 2014). However, the occurrence of megafires (wildfires > $100 \mathrm{~km}^{2}$ ) has become globally prevalent, the causes of which include climate change, accumulated fuels, and anthropogenic disturbance (Stephens et al. 2014). The megafire phenomenon is especially evident in the western USA, where higher air temperatures and earlier snowmelt associated with climate change coupled with elevated fuel loads from $100+y$ of fire suppression have resulted in greater wildfire frequency, size, and intensity (Westerling et al. 2006, Hurteau et al. 2014). Changes in wildfire regimes are predicted to accelerate and intensify as a result of climate change in the decades to come (Brown et al. 2004, McKenzie et al. 2004, Moritz et al. 2012), with numerous and potentially severe consequences for stream biota throughout cold- and warmwater systems (Gresswell 1999). However, most information concerning wildfire effects on streams has come from single wildfire events in cold headwater systems (Gresswell 1999), so predictions concerning the effects of future fire regimes on native and nonnative species in warmwater systems are difficult to make.

The effects of wildfires on stream communities can be partitioned into those that are direct and immediate vs those that are indirect and delayed (Gresswell 1999, Rieman et al. 2012). Direct effects from heat dissipation, ash deposition, and smoke diffusion associated with burning a stream's riparian corridor can increase water temperature (Hall and Lantz 1969, Hitt 2003), pH (Cushing and Olson 1963), and nutrient concentrations (N and P; Spencer and Hauer 1991). Direct effects are least pronounced in larger streams because greater water volume buffers larger streams against such changes. Direct effects are short lived and are considered pulse disturbances (Niemi et al. 1990, Gresswell 1999). Indirect effects result from a wildfire's alteration of

E-mail addresses: ${ }^{3}$ Present address: Missouri Cooperative Fish and Wildlife Research Unit, Department of Fisheries and Wildlife Sciences, University of Missouri, Columbia, Missouri65211 USA, whitneyj@missouri.edu; ${ }^{4}$ kgido@ksu.edu; ${ }^{5}$ tjpilger@unm.edu; ${ }^{6}$ tiaroga@comcast.net; ${ }^{7}$ turnert@unm.edu

DOI: 10.1086/683391. Received 20 November 2014; Accepted 5 February 2015; Published online 27 August 2015.

Freshwater Science. 2015. 34(4):1510-1526. ๑ 2015 by The Society for Freshwater Science. 
watershed vegetation and soil characteristics and include increased water yield (Legleiter et al. 2002) and sedimentation (Benda et al. 2003), decreased inputs of large woody debris (May and Gresswell 2003), increased temperature from a loss of canopy cover (Dunham et al. 2007, Sestrich et al. 2011), and altered quantity and quality of resource inputs (Mihuc and Minshall 1995, Malison and Baxter 2010). Similar to direct effects, indirect effects also attenuate with stream size. However, indirect effects are considered press disturbances because they can last for several hundred years or until the forest regenerates to prewildfire conditions (Minshall et al. 1989).

The impact of wildfire on streams is related to the characteristics of the wildfire itself, the focal stream, and postfire precipitation (Gresswell 1999, Rieman et al. 2012). Wildfire characteristics include size, severity (influence on soil), intensity (effects on vegetation), and timing (Brown 1990). Stream features that dictate wildfire effects include volume, distance from the fire, time since previous wildfire, and catchment characteristics (geology, topography, vegetation, soil, and geomorphology). Repeated wildfires in a catchment could additively or synergistically influence biota by eliminating refuges and resetting habitat and population recovery trajectories, and greater fire frequency could lead to more extirpations and prevent ecosystem recovery. Postfire precipitation on a recently burned catchment produces ash flows that can, depending on timing and intensity, result in hypoxic water conditions (Lyon and O'Connor 2008), high suspended sediment loads (Bozek and Young 1994), and extreme flooding (Rinne 1996, Vieira et al. 2004, Howell 2006). To account for this context dependency, it is important to document stream characteristics, fire characteristics, and postfire precipitation in assessing the effects of wildfire on riverine communities.

Given their numerous physical effects on rivers, wildfires can affect stream biota in multiple ways. For instance, wildfire-induced changes in channel stability, sedimentation, and resource availability can decrease macroinvertebrate abundance (Gresswell 1999). Wildfire-induced habitat changes have resulted in altered macroinvertebrate community composition by selecting for taxa with shorter turnover times, high dispersal abilities, or autochthonous resource preferences (Mihuc and Minshall 1995, Vieira et al. 2004, Verkaik et al. 2013). Wildfire-induced flooding also can severely alter macroinvertebrate abundance, richness, and community structure (Rinne 1996, Earl and Blinn 2003, Vieira et al. 2004). Fish are susceptible to postwildfire hydrologic events but appear less affected by habitat changes because populations recover faster (1-3 y; Rieman et al. 1995) than habitat ( $\geq 10$ y; Gresswell 1999, Rosenberger et al. 2011). Complex life histories (i.e., require movement among multiple habitats for feeding, spawning, rearing, and refuge), high dispersal propensity, and connectivity confer resilience and support rapid recolonization by fishes
(Rieman and Dunham 2000, Burton 2005). Ash flows have the greatest effect on fish communities because these postfire hydrologic events result in mass mortality and extirpation (Propst et al. 1992, Bozek and Young 1994, Rinne 1996).

Most studies of biotic response to wildfires have been done in cold headwater systems (Rieman et al. 1995, 2003, Rieman and Clayton 1997). Coldwater (streams with maximum daily mean temperatures $<22^{\circ} \mathrm{C}$; Lyons et al. 1996) fish communities generally are dominated by salmonids, which are stenothermic, have low tolerance for poor water quality, and are highly mobile (Quinn 2005, Richter and Kolmes 2005). The low physiologic tolerance of salmonids to hypoxia explains their limited resistance to wildfireinduced ash flows (Doudoroff and Shumway 1970), and their complex life histories confer their high resilience and rapid recovery (Rieman and Dunham 2000). The response in warmwater systems (streams with maximum daily mean water temperature $>24^{\circ} \mathrm{C}$ ) containing more diverse fish communities (e.g., cyprinids, catostomids, ictalurids, and centrarchids) with their associated life histories, physiological tolerances, and movement capabilities are not well investigated and, thus, are poorly understood (Rieman et al. 2003). Warmwater species may be more resistant to wildfire because of their greater thermal and hypoxia tolerances (Smale and Rabeni 1995) but may be less resilient if they possess low dispersal ability. These differences in species' traits could result in divergent responses and unequal susceptibility of cold- and warmwater communities to fire disturbance, but the paucity of studies in warmwater systems (but see Lyon and O'Connor 2008) makes identification of systematic differences problematic. More research on wildfire effects on warmwater streams is needed to determine if such systematic differences exist.

Nonnative species are another agent of change affecting streams in western North America. Many nonnative fishes documented in the Colorado River Basin have divergent life histories (low fecundity, high parental care), habitat preferences (warm water, limnophilic), and trophic strategies (secondary and tertiary consumers) relative to native species (Olden et al. 2006, Pilger et al. 2010), and some introduced species represent lineages previously absent in the Colorado River Basin (e.g., ictalurids, percids, and centrarchids; Olden et al. 2006). Given their functional and taxonomic divergence, these nonnatives have been hypothesized to be differentially susceptible to wildfire disturbance relative to natives (Dunham et al. 2003, Young 2012). For instance, species introduced from watersheds where wildfire is rare or absent, as is the case for most nonsalmonid Colorado River nonnatives (Olden et al. 2006, Parisien and Moritz 2009), may lack adaptations necessary to withstand this disturbance. In contrast, the traits that allowed for successful invasion (habitat and trophic generalist, high environmental tolerance, and dispersal) may also confer resistance to wildfire disturbance (Dunham et al. 2003). 
Studies investigating these competing hypotheses are limited to native and nonnative salmonids occurring in coldwater systems and suggest similar susceptibility of both natives and nonnatives to wildfire disturbance (Sestrich et al. 2011). Efforts to conserve native and suppress nonnative biota under a changing fire regime would benefit from a greater understanding of both of their responses to wildfires of different size and intensity, of single vs repeated wildfires, and across streams of different catchment and thermal characteristics. The objectives of our research were to quantify short-term, taxon-specific responses of oligochaetes, insects, crayfish, fishes, and tadpoles to single and repeated wildfire events in cold- and warmwater habitats of the upper Gila River. We also compared the responses to wildfires of native and nonnative fishes and examined the effects of wildfire on habitat and resource availability to identify potential bottom-up drivers of biotic change. We hypothesized that abiotic and biotic responses to wildfire would decrease with increasing stream size and distance from wildfire because of buffering by greater water volume, that coldwater fishes would be more susceptible to wildfire effects than warmwater fishes because of greater sensitivity to poor water quality, and that native fishes would be less affected than nonnative fishes because of their evolutionary history with wildfire.

\section{METHODS}

\section{Study area}

Our study was conducted across 3 longitudinal zones (tributary, canyon, and valley) in the upper Gila River of southwestern New Mexico, USA, with 2 sites positioned in each zone (Fig. 1). Longitudinal zones were defined by stream size, surrounding geology, and elevation (Table 1). The 2 sites in the tributary zone were on the West (tributary 1) and Middle (tributary 2) Forks of the Gila River, whereas the 4 sites in the canyon (canyon 1 and 2) and valley (valley 1 and 2) zones were on the Gila River mainstem. Based on the definition by Lyons et al. (1996), tributary 1 was classified as cold water and the other 5 sites as warm water (Table 1). Large temperature differences between tributary 1 and tributary 2 result from aspect and several hot-spring inputs throughout tributary 2. Temperature classifications were supported by differences in fish communities across sites because tributary 1 is the only site with salmonids as common community members (Whitney et al. 2014). Mean stream width was lowest in tributary 1 and increased downstream across longitudinal zones, although mean depth was generally greatest in the canyon (Table 1). Tributary and canyon catchments were composed primarily of mixed-conifer forest, including ponderosa pine (Pinus ponderosa), piñon pine (Pinus spp.), Douglas fir (Pseudotsuga menziesii), and juniper (Juniperus spp.). Valley sites had riparian zones modified by agricul-

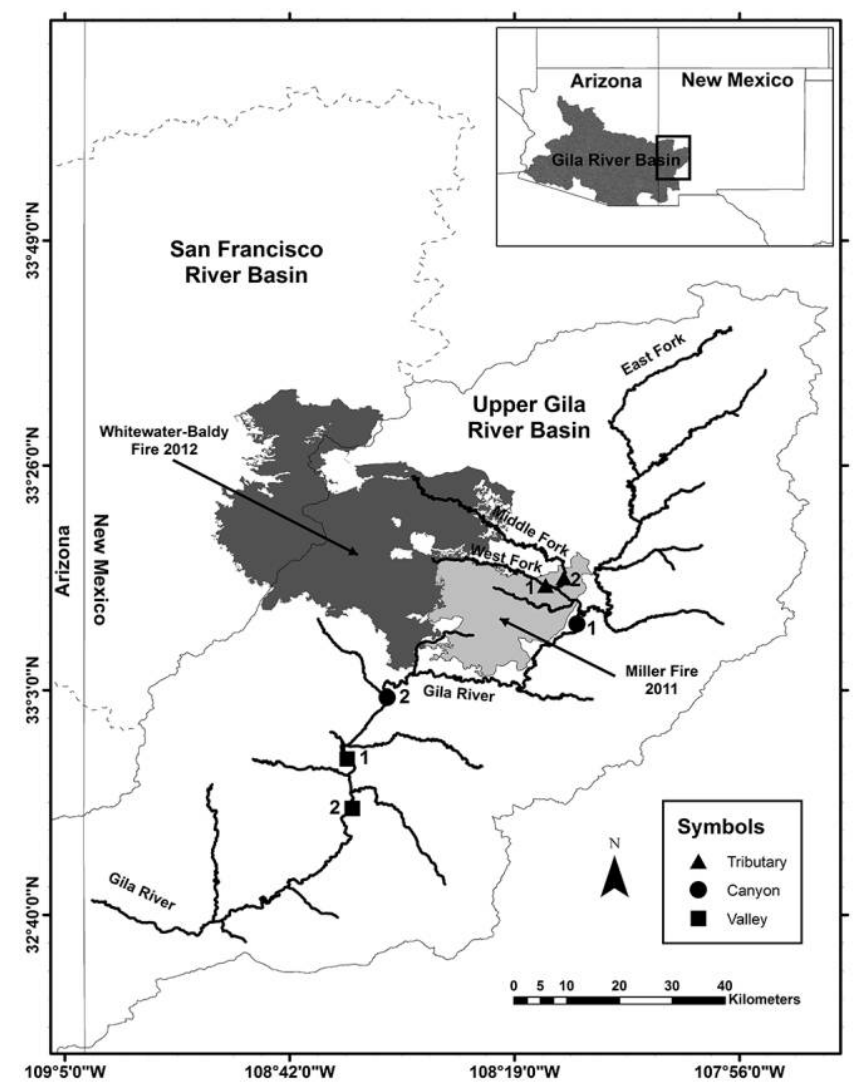

Figure 1. Study site locations and wildfire perimeters in the upper Gila River Basin, New Mexico, USA. Tributary 1 is on the West Fork and tributary 2 is on the Middle Fork. Canyon 1 and valley 1 are the more upstream sites in their respective zones. Tributary 1 is the only coldwater site, whereas all other sites are warm water.

ture (mainly irrigated pasture) and scattered human settlement in the floodplain. Riparian areas were composed of willow (Salix spp.), cottonwood (Populus spp.), and sycamore (Plantanus spp.) regardless of longitudinal zone.

\section{Wildfire characteristics}

All study sites were affected by consecutive wildfires in 2011 and 2012. The Miller fire (fire 1) was proximal to the 3 upper study sites and burned relatively smaller watershed areas, whereas the Whitewater-Baldy fire (fire 2) was more proximal to the 3 lower study sites and burned larger watershed areas. From 17 April through 6 June 2011, fire 1 burned $359 \mathrm{~km}^{2}$ (Fig. 1). This fire burned the riparian areas of both tributary sites but burned a greater percentage of watershed area in tributary 1 (Table 1). Distance from the fire 1 perimeter increased downstream for other study sites, whereas \% watershed area burned remained relatively constant ( 5-7\%; Table 1$)$. The following year, fire 2 burned an additional $1205 \mathrm{~km}^{2}$ of the Gila National Forest between 9 May and 23 July, $755 \mathrm{~km}^{2}$ of which were in the upper 
Table 1. Study site characteristics in the upper Gila River Basin, New Mexico, USA. Maximum mean daily water temperature was recorded every $2 \mathrm{~h}$ from 01 July 2011 to 30 June 2012 with $\mathrm{HOBO}^{\circledR}$ temperature loggers, whereas mean width, depth, and sample area were calculated during March, June, and October 2011-2013 (see Whitney et al. 2014 for methods). Elevation was obtained from Google Earth ${ }^{\circledR}$. Temperature classifications (cold water $<22^{\circ} \mathrm{C}$, warm water $>24^{\circ} \mathrm{C}$ ) are from Lyons et al. (1996). Sampling area was calculated as mean site width $\times$ length. Total watershed area and watershed area burned were calculated in a geographic information system. Miller and Whitewater distance are the shortest watercourse distance from a study site to the perimeter of each wildfire and were measured using Google Earth.

\begin{tabular}{|c|c|c|c|c|c|c|c|}
\hline \multirow[b]{2}{*}{ Characteristic } & \multirow[b]{2}{*}{ Units } & \multicolumn{2}{|c|}{ Tributary } & \multicolumn{2}{|c|}{ Canyon } & \multicolumn{2}{|c|}{ Valley } \\
\hline & & Site 1 & Site 2 & Site 1 & Site 2 & Site 1 & Site 2 \\
\hline Waterbody & - & West Fork & Middle Fork & Mainstem & Mainstem & Mainstem & Mainstem \\
\hline $\begin{array}{l}\text { Maximum mean daily } \\
\text { temperature }\end{array}$ & ${ }^{\circ} \mathrm{C}$ & 18.7 & 26.8 & 23.5 & 25.5 & 24.1 & 24.8 \\
\hline Temperature classification & - & Cold water & Warm water & Warm water & Warm water & Warm water & Warm water \\
\hline Elevation & $\mathrm{m}$ asl & 1738 & 1725 & 1691 & 1412 & 1360 & 1331 \\
\hline Mean depth & $\mathrm{m}$ & 0.18 & 0.35 & 0.36 & 0.43 & 0.27 & 0.32 \\
\hline Mean sampling area & $\mathrm{m}^{2}$ & 1237 & 1776 & 3909 & 2051 & 2290 & 3098 \\
\hline Watershed area & $\mathrm{km}^{2}$ & 312 & 885 & 3857 & 5133 & 6290 & 7161 \\
\hline Miller area burned & $\mathrm{km}^{2}(\%)$ & $95(30)$ & $15(2)$ & $227(6)$ & $359(7)$ & $359(6)$ & $359(5)$ \\
\hline Whitewater area burned & $\mathrm{km}^{2}(\%)$ & $158(51)$ & $322(36)$ & $480(12)$ & $722(14)$ & $755(12)$ & $755(11)$ \\
\hline Total area burned & $\mathrm{km}^{2}(\%)$ & $253(81)$ & $337(38)$ & $754(18)$ & $1128(21)$ & $1161(18)$ & $1161(16)$ \\
\hline Miller distance & $\mathrm{km}$ & 0.0 & 0.0 & 1.3 & 19 & 35 & 46 \\
\hline Whitewater distance & $\mathrm{km}$ & 21 & 24 & 32 & 10 & 25 & 38 \\
\hline
\end{tabular}

Gila River Basin. Tributary 1 had the greatest percentage of watershed area burned, and all sites had greater watershed area affected by this wildfire. However, study-site distance from the fire 2 perimeter was greater for the 3 upper sites relative to fire 1 , and canyon 2 had the most proximal position to the fire perimeter. Both wildfires were unusually large because fires $>10 \mathrm{~km}^{2}$ were historically a rare component of the southwestern fire regime (Dietrich 1983, Swetnam 1990). These fires were also severe, stand-replacing crown fires. Thus, their perimeters were adjacent but generally nonoverlapping given the lack of fuel following the initial fire. Total watershed area burned was greatest for more downstream sites, but \% of total watershed burned was greatest for the tributary sites. Fire-generated ash washed through our study sites during the monsoon seasons after each fire. Fire 1 was followed by a relatively strong monsoon season (mean daily discharge [MDD] during 01 July to 30 September $=2.72 \mathrm{~m}^{3} / \mathrm{s}$, maximum $\mathrm{MDD}=31.7 \mathrm{~m}^{3} / \mathrm{s}$; US Geological Survey [USGS] gage 09430500), whereas a relatively weak monsoon season followed fire 2 (MDD = $1.81 \mathrm{~m}^{3} / \mathrm{s}$, maximum MDD $=5.24 \mathrm{~m}^{3} / \mathrm{s}$ ).

\section{Comparison of flow regimes}

Annual variation in flows can drive changes in habitat, resource availability, and communities in the upper Gila River (Propst et al. 2008, Stefferud et al. 2011, Gido et al. 2013) and mediates wildfire effects on biota (Rugenski and
Minshall 2014). Therefore, we calculated several annual flow indices across the study period to evaluate potential confounding effects with wildfire. Important periods of the annual flow regime in southwestern streams include spring snowmelt, summer low flow, and the monsoon season, so we chose flow-regime metrics that describe these periods to evaluate the possibility that temporal differences in flow regime, which might or might not be related to wildfire, accounted for observed changes in response variables. We calculated annual mean daily discharge (MDD), mean spring discharge (MDD 01 March-30 June), coefficient of variation $(\mathrm{CV})$ of summer MDD (standard deviation/mean daily discharge during 01 July-30 September), and baseflow index (smallest values of MDD computed over any 7 consecutive days during the annual period divided by mean annual flow; larger values are representative of more consistent flows). These flow-regime metrics were chosen because Gido et al. (2013) established that these were the most important of a larger suite of metrics for describing abundance patterns of native and nonnative fishes. Flowregime metrics were calculated for the year before the fires (1 July 2010-30 June 2011) and the years after fire 1 (1 July 2011-30 June 2012) and fire 2 (1 July 2012-30 June 2013) and as long-term values (1927-2013) based on USGS data from Gila River near the Gila gage (09430500). Changes in response variables after wildfire without large differences in flow-regime metrics provided greater evidence for a wildfire effect than a stream discharge effect. 


\section{General sampling design}

All sampling was done during March, June, and October to capture seasonal variation, starting in October 2010 and ending in June 2013, which gave us 9 total sampling occasions ( 3 prefire, 3 post-first fire, and 3 post-second fire). Habitat was not measured in October 2010 (prefire) for any site, and habitat and stream macroconsumers (i.e., crayfish, tadpoles, and fishes) were not sampled in March 2011 (prefire) at canyon 2, valley 1, and valley 2 because of logistical constraints. Sampling was conducted at the mesohabitat scale (pool or riffle), with 6 mesohabitats (3 pools and 3 riffles) in tributary sites and 4 mesohabitats ( 2 pools and 2 riffles) in mainstem sites. Mesohabitat area was calculated by multiplying mean width (2-3 widths/mesohabitat) by length of each mesohabitat. Mean sampling area for each site (summed across mesohabitats) is presented in Table 1. Grand site means were calculated from values of mesohabitat response variables by habitat area-weighted averaging.

\section{Habitat}

The \% cover of silt ( $>4$ to $<62 \mu \mathrm{m}$; Wood and Armitage 1997) was estimated by quantifying substrate at 5 points along 2 (tributary) to 3 (mainstem) transects in each mesohabitat. The length and width of large woody debris (LWD; i.e., circumference $\geq 0.05 \mathrm{~m}$ and length $\geq 0.3 \mathrm{~m}$ ) was measured to estimate \% cover of LWD.

\section{Resource availability}

Chlorophyll $a$ was sampled by collecting and pooling 3 rocks along 6 transects from an equal number of pool and riffle mesohabitats to quantify autochthonous resource availability. The rock samples were kept in the dark and frozen until chlorophyll $a$ was extracted with 95\% ethanol and analyzed spectrophotometrically following the methods of Steinman et al. (2006). Chlorophyll $a$ concentrations were then corrected for rock surface area and expressed as $\mu \mathrm{g}$ chlorophyll $a / \mathrm{cm}^{2}$.

\section{Benthic macroinvertebrates}

Benthic macroinvertebrates were sampled from pool mesohabitats with a stovepipe core $\left(0.018 \mathrm{~m}^{2}\right)$, from riffle mesohabitats with a Surber sampler $\left(0.093 \mathrm{~m}^{2}\right.$; mesh $=$ $250 \mu \mathrm{m}$ ), and from LWD by scrubbing and removing individuals from pieces of LWD (average surface area $=0.035 \mathrm{~m}^{2}$ ). Two (tributary) to 3 (mainstem) replicates were taken for each habitat type, with replicates pooled into a single sample for each habitat type and preserved in $10 \%$ formalin. Individuals were separated from inorganic debris and organic detritus and measured for total length. Insects were identified to family with keys provided by Merritt et al. (2008), whereas noninsects were identified to phylum or class with keys provided by Thorp and Covich (2001). Biomass was calculated based on published length-mass rela- tionships of the lowest identified taxonomic unit (Burgherr and Meyer 1997, Benke et al. 1999, Sabo et al. 2002) and was expressed as mg dry mass $(\mathrm{DM}) / \mathrm{m}^{2}$. To examine overall community responses, aggregate biomass values were calculated based on taxonomic groups (summed biomass of Oligochaeta and Insecta) and for taxa that may be particularly sensitive to habitat changes induced by wildfire and flow (summed biomass of Ephemeroptera, Plecoptera, and Trichoptera [EPT]; summed biomass of Odonata, Coleoptera, and Hemiptera [OCH]; Bonada et al. 2007).

\section{Stream macroconsumers}

Stream macroconsumers (nonnative crayfish, nonnative tadpoles, native and nonnative fishes) were sampled during a single pass that in pools included a combination of backpack electrofishing with 1 or 2 dip-netters upstream followed by seining $(4.6 \times 1.2 \mathrm{~m}, 3.2-\mathrm{mm}$ mesh) downstream and in riffles used electrofishing downstream into a seine. Whitney et al. (2014) found these techniques effective for estimating abundance of stream macroconsumers in the upper Gila River, New Mexico, when compared with multiple-pass sampling. Our sampling methods do not capture native tadpoles, possibly because of their smaller size or shorter aquatic life stage relative to nonnative tadpoles. All crayfish in the Gila River Basin are nonnative (Moody and Taylor 2012). Captured individuals were identified to species, measured for total length, and returned alive to their respective mesohabitat. Species biomass was calculated based on previously quantified length-mass relationships specific to the upper Gila River (Whitney et al. 2014) and was expressed as g wet mass (WM) $/ \mathrm{m}^{2}$. Summed biomass of native and nonnative fishes was calculated to examine overall community responses.

\section{Analysis}

All analyses were conducted in R (version 3.1.0; R Project for Statistical Computing, Vienna, Austria). Biomass was $\log _{10}(x)$-transformed (chlorophyll $a$ ) or $\log _{10}(x+1)$ transformed (macroinvertebrates and macroconsumers) before analyses to satisfy assumptions of normally distributed errors and homoscedasticity. Changes in habitat, resource availability, and the biomass of taxonomic groups after the 2 fires were assessed statistically with a 2-way repeated-measures analysis of variance (rmANOVA). This analysis included interactive effects of site and time period (prefire, $1^{\text {st }}$ wildfire, $2^{\text {nd }}$ wildfire) and included sampling month as the repeated factor. Site was treated as a fixed effect because we were interested in the response at each site, with site location chosen a priori to create a natural experimental framework that would allow investigation of the effects of catchment and wildfire characteristics on site responses. Spatial autocorrelation was not incorporated into the structure of this analysis because an earlier study revealed large differences in abiotic and biotic properties 
over small spatial distances associated with rapid transitions within (coldwater tributary 1 vs warmwater tributary 2) and between longitudinal zones (tributary 1 or 2 vs canyon 1 , canyon 2 vs valley 1 ; Whitney et al. 2014). Results were considered significant at $p \leq 0.05$ and marginally significant at $p \leq 0.10$. If a significant or marginally significant site $\times$ time interaction was detected, pairwise Bonferroni-adjusted $t$-tests comparing time periods within sites were conducted. The main effect of site was not of interest in our study and was investigated only to identify spatially variable changes after wildfires (i.e., a site $\times$ time interaction). Therefore, post hoc differences among sites were not examined unless a significant site $\times$ time interaction was found. Only the responses of common macroinvertebrates (i.e., noninsects that, on average, made up $>10 \%$ of total macroinvertebrate biomass; insect families that, on average, made up $>10 \%$ of total insect biomass) and stream macroconsumers (i.e., \% occurrence $>10 \%$ ) were analyzed.

\section{RESULTS}

\section{Comparison of flow regimes}

Discharge was lower than long-term averages during the 3 study years (Table 2). CV of summer discharge was high the year after the $1^{\text {st }}$ fire and differed from other study years and from the long-term CV. The baseflow index was similar among study years and the long-term baseflow index value. Given that all study years had similar flow regimes (i.e., low discharge from drought conditions), any observed changes in habitat, resource availability, and biotic responses was expected to be resultant from the effects of wildfire, but consecutive years of drought conditions also might result in cumulative effects on stream biota.

\section{Habitat}

Fire and subsequent ash flows generally increased \% silt and decreased \% LWD across our sites, but some time- and site-specific responses were found. Percent silt varied marginally across time $\left(F_{2,4}=4.73, p=0.088\right)$ and significantly among sites $\left(F_{5,22}=9.45, p<0.001\right)$, but these factors did not interact $\left(F_{10,22}=1.63, p=0.164\right.$; Table 3$)$. Mean \% silt across sites more than doubled from $9 \pm 8 \%$ (mean \pm SD) prefire to $21 \pm 14 \%$ after fire $2(p=0.024)$ but was only $12 \pm 11 \%$ after fire 1 , which did not differ from the prefire period ( $p=0.857)$. Percent LWD showed a time $\times$ site interaction $\left(F_{10,22}=3.24, p=0.010\right)$. Only one site exhibited decreased \% LWD following fire 1 (canyon 1, 28\% decrease), whereas fire 2 elicited a stronger response. Percent LWD decreased $70 \%$ at tributary $2,57 \%$ at canyon $1,56 \%$ at valley 1 , and $69 \%$ at valley 2 (Fig. 2A) between fire 1 and fire 2 .

\section{Resource availability}

Chlorophyll $a$ concentration generally declined after the fires, but the time $\times$ site interaction was significant $\left(F_{10,30}=2.53, p=0.024\right.$; Table 3$)$. Back-transformed chlorophyll $a$ concentration averaged across all sites decreased by $77 \%$ from prefire conditions to after fire 2 and decreased by 35 to $48 \%$ between fire 1 and fire 2 at the 3 lowermost sites (canyon 2, valley 1 and 2; Fig. 2B). Chlorophyll $a$ concentration averaged across sites was unchanged after fire 1.

\section{Benthic macroinvertebrates}

Eleven classes of macroinvertebrates were encountered during sampling: Turbellaria (flatworms), Oligochaeta (segmented worms), Clitellata (leeches), Gastropoda (snails and limpets), Bivalvia (nonnative Asian clam Corbicula fluminea), Arachnida (water mites), Insecta (insects), Branchiopoda (cladocerans), Maxillopoda (copepods), Ostracoda (seed shrimp), and Malacostraca (scuds) (Appendix S1 lists all taxa encountered). Members of the phyla Nematomorpha, Nematoda, and Nemertea also were collected but were not identified beyond phylum. Oligochaeta and Insecta composed the major portion of macroinvertebrate biomass and accounted for 95\% (range $=73.0-99.9 \%$ ) of total sample biomass averaged across sites and time. Because of this dominance and the rarity of other groups, segmented worms and insects were the only macroinvertebrates examined statistically. Oligochaeta biomass differed among sites but was unaffected by wildfires. Back-transformed Insecta biomass averaged across sites decreased by $82 \%$ from $1818(95 \%$ confidence interval $=1277-2589) \mathrm{mg} / \mathrm{m}^{2}$ in the prefire period to $327(179-599) \mathrm{mg} / \mathrm{m}^{2}$ after fire $2(\mathrm{Ta}-$ ble 3). EPT (33.7\% of total insect biomass) and $\mathrm{OCH}$ (12.7\% of total insect biomass) exhibited similar changes after 2 fires, decreasing by $89 \%$ from 557 (322-961) to 59 (29-118) $\mathrm{mg} / \mathrm{m}^{2}$ and by $83 \%$ from $126(74-214)$ to 22 (9.9-45.6) $\mathrm{mg} / \mathrm{m}^{2}$, respectively.

Table 2. Flow-regime characteristics for the 3 study periods and for the period of record. Spring was defined as 1 March30 June, and summer was defined as 1 July-30 September. MDD = mean daily discharge, CV = coefficient of variation.

\begin{tabular}{lccccc}
\hline Time period & Dates & Annual MDD $\left(\mathrm{m}^{3} / \mathrm{s}\right)$ & Spring MDD $\left(\mathrm{m}^{3} / \mathrm{s}\right)$ & Summer CV & Baseflow index \\
\hline Prefire & July 2010-June 2011 & $2.04(1.59)$ & $1.24(0.46)$ & 0.74 & 0.26 \\
First fire & July 2011-June 2012 & $2.56(2.39)$ & $2.12(1.15)$ & 1.49 & 0.21 \\
Second fire & July 2012-June 2013 & $2.07(1.35)$ & $2.35(1.87)$ & 0.48 & 0.18 \\
Long-term & 1927-2013 & $4.43(2.25)$ & $5.02(2.69)$ & 0.46 & 0.27 \\
\hline
\end{tabular}


Table 3. $p$-values and site responses from repeated-measures analysis of variance investigating the interactive effects of site and time. Significant $(p \leq 0.05)$ or marginally significant $(p \leq 0.10)$ time or site $\times$ time interactions are in bold. Post hoc analyses for significant site effects only were not examined, so significant site effects are not in bold. Response variables are arranged according to time response and then site response so that taxa with similar wildfire responses are positioned together. All reported inequalities are decreases across time periods except for \% silt across all sites and Cyprinella lutrensis biomass at canyon 2 after the $1^{\text {st }}$ fire, which were increases. Tri $=$ tributary; $\mathrm{Can}=$ canyon; $\mathrm{Val}=$ valley; $\mathrm{LWD}=$ large woody debris; EPT $=$ Ephemeroptera, Plecoptera, Trichoptera; OCH = Odonata, Coleoptera, Hemiptera; * = nonnative taxon. See Appendix S1 for common names.

\begin{tabular}{|c|c|c|c|c|c|c|}
\hline Response variable & Site & Time & Site $\times$ time & First fire $\neq$ prefire & Second fire $\neq$ pre-fire & First fire $\neq$ second fire \\
\hline Corixidae & 0.023 & 0.044 & 0.413 & All & - & - \\
\hline Rhinichthys osculus & $<0.001$ & 0.022 & $<0.001$ & Tri1, Can1 & - & - \\
\hline Nonnative fish & $<0.001$ & 0.537 & 0.073 & Tri1 & - & - \\
\hline Oncorhynchus mykiss* & $<0.001$ & 0.015 & $<0.001$ & Tri1 & - & - \\
\hline Salmo trutta* & $<0.001$ & $<0.001$ & $<0.001$ & Tri1 & - & - \\
\hline Gila nigra & 0.003 & 0.002 & 0.034 & Tri2 & - & - \\
\hline Pimephales promelas* & 0.025 & 0.836 & 0.083 & Tri2 & - & - \\
\hline Tiaroga cobitis & $<0.001$ & 0.007 & $<0.001$ & Can1 & - & - \\
\hline Ictalurus punctatus* & 0.036 & 0.056 & 0.026 & Can2 & - & - \\
\hline Pylodictis olivaris* & $<0.001$ & 0.42 & 0.015 & Can2 & - & - \\
\hline Micropterus dolomieu* & $<0.001$ & 0.009 & 0.002 & Can2 & - & - \\
\hline$\%$ silt & $<0.001$ & 0.088 & 0.164 & - & All & - \\
\hline Gomphidae & 0.25 & 0.033 & 0.572 & - & All & - \\
\hline Leptohyphidae & 0.002 & 0.047 & 0.272 & - & All & - \\
\hline Tabanidae & 0.002 & 0.003 & 0.264 & - & All & - \\
\hline Lepomis cyanellus* & $<0.001$ & 0.02 & 0.006 & - & Can2, Val1 & - \\
\hline Chironomidae & $<0.001$ & 0.268 & 0.056 & - & Can2 & - \\
\hline Cyprinus carpio** & $<0.001$ & 0.837 & $<0.001$ & - & Can2 & - \\
\hline Libellulidae & 0.004 & 0.153 & 0.093 & Tri1 & Can2 & - \\
\hline Meda fulgida & 0.001 & 0.092 & 0.007 & Tri2 & Val1 & - \\
\hline Agosia chrysogaster & $<0.001$ & 0.02 & 0.015 & Tri2, Can2 & Val2 & - \\
\hline Native fish & $<0.001$ & 0.022 & 0.035 & Can1 & Tri2, Can1, Can2, Val2 & - \\
\hline Crambidae & 0.117 & 0.004 & 0.212 & All & - & All \\
\hline Hydropsychidae & 0.16 & 0.034 & 0.160 & All & - & All \\
\hline \% LWD & $<0.001$ & 0.023 & 0.010 & Can1 & - & Tri2, Can1, Val1, Val2 \\
\hline Cyprinella lutrensis* & 0.014 & 0.01 & 0.019 & Can2 & - & Can2 \\
\hline Insecta & 0.018 & 0.098 & 0.459 & - & All & All \\
\hline EPT & 0.008 & 0.068 & 0.548 & - & All & All \\
\hline $\mathrm{OCH}$ & 0.13 & 0.074 & 0.673 & - & All & All \\
\hline Chlorophyll $a$ & $<0.001$ & 0.003 & 0.024 & - & All & Can2, Val1, Val2 \\
\hline Catostomus insignis & $<0.001$ & 0.032 & 0.014 & - & Tri2, Val2 & Tri2 \\
\hline
\end{tabular}

Nine Insecta orders represented by 62 families were collected. Coleoptera and Diptera had the greatest number of families (13 each), whereas Megaloptera (Corydalidae) and Lepidoptera (Crambidae) were each represented by a single family. Among these 62 families, 26 were common enough to warrant investigation into their spatiotemporal changes in biomass and on average represented $88 \%$ (range $=29.5-99.9 \%)$ of total Insecta biomass. Several insect families varied significantly by time, but the site $\times$ time interaction was not significant (Table 3). These dif- ferences included decreases in biomass of Corixidae (85\%) (Fig. 3A), Hydropsychidae (25\%) (Fig. 3B), and Crambidae (60\%) (Fig. 3C) from prefire conditions to after fire 1 and of Gomphidae (82\%) (Fig. 3D), Leptohyphidae (64\%) (Fig. 3E), and Tabanidae (54\%) (Fig. 3F) from the prefire period to after fire 2. Hydropsychidae and Crambidae also decreased from after fire 1 to after fire 2, when their biomasses were 35 and $89 \%$ lower, respectively, than after fire 1 . These sequential decreases resulted in a cumulative decrease of $51 \%$ for Hydropsychidae and 96\% for Crambidae after 2 

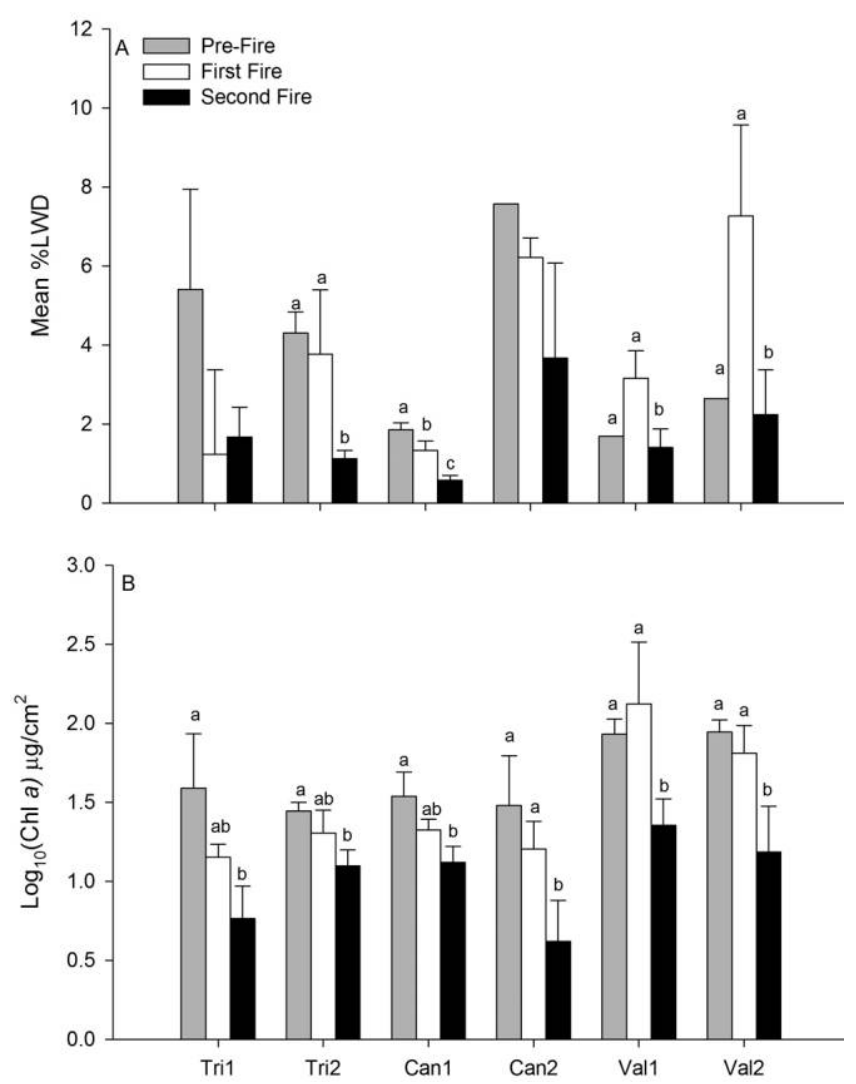

Figure 2. Mean (+1 SD) \% large woody debris (LWD) (A) and chlorophyll $a(\mathrm{Chl} a$ ) concentration (B) across 6 sites before and after consecutive wildfires in the upper Gila River Basin, New Mexico, USA. See Table 3 for statistical results. Letters denote differences among time periods within sites, not among sites. Bars with the same letters are not significantly different. Tri $=$ tributary, Can $=$ canyon, Val $=$ valley .

fires. More spatially limited wildfire-associated decreases occurred for 2 insect families. Libellulidae back-transformed biomass decreased from $17(1-137)$ to $0 \mathrm{mg} / \mathrm{m}^{2}$ at tributary 1 after fire 1 and from $8(0-80)$ to $0 \mathrm{mg} / \mathrm{m}^{2}$ at canyon 2 after 2 fires. Chironomidae decreased from 69 (49-97) to $11(3-41) \mathrm{mg} / \mathrm{m}^{2}$ after 2 fires at canyon 2.

\section{Stream macroconsumers}

Seven of 8 native and 11 of 12 nonnative fish species collected were common enough to warrant statistical investigation. We also collected the nonnative virile crayfish Orconectes virilis and American bullfrog tadpole Lithobates catesbeianus (the only crayfish and tadpole collected, respectively; Appendix S1). Aggregate native fish biomass decreased after fire 1 at canyon $1(58 \%)$ and after 2 fires at tributary $2(73 \%)$, canyon $2(99 \%)$, and valley $2(89 \%)$ (Fig. 4A). Total nonnative fish biomass decreased by $100 \%$ at tributary 1 (cold water) after fire 1 but was unresponsive at other locations (Fig. 4B). Neither O. virilis nor L. catesbeianus responded to fire.
Six of 7 native fishes declined significantly after fire 1 or 2. These changes were spatially dependent. Upper sites (tributary 1 and 2 , canyon 1 ) generally experienced decreases after the $1^{\text {st }}$ fire, whereas lower sites (canyon 2, valley 1 and 2) experienced decreases after 2 fires. Native fish decreases after wildfires were spatially patchy within regions (upper or lower). Tributary 2 experienced more decreases among native fishes than did the other upper sites after fire 1 , and valley 2 experienced more decreases than did the other lower sites after 2 fires. For instance, native Longfin Dace Agosia chrysogaster (81\%) (Fig. 5A), Headwater Chub Gila nigra (100\%) (Fig. 5B), and Spikedace Meda fulgida (100\%) (Fig. 5C) all exhibited significant decreases in biomass at tributary 2 after fire 1 (Table 3). Speckled Dace Rhinichthys osculus (Fig. 5D) and Loach Minnow Tiaroga cobitis (Fig. 5E) had low biomass at canyon 1 before fire 1 , and they exhibited decreases of 93 and 84\%, respectively, after fire 1. Rhinichthys osculus also decreased by $62 \%$ at tributary 1 (cold water), where its biomass was relatively high before fire 1 . Canyon 2 was the only lower site to exhibit changes in native biomass after fire 1 , with A. chrysogaster biomass decreasing by an order of magnitude. After 2 fires, A. chrysogaster and Sonora Sucker Catostomus insignis (Fig. 5F) decreased by 87 and 93\%, respectively, at valley 2 , and $M$. fulgida decreased by $99 \%$ at valley 1 . The only upper site to exhibit changes in native biomass after 2 fires was tributary 2 where C. insignis decreased $86 \%$ from after fire 1 to after fire 2. Desert Sucker Pantosteus clarkii was the only native fish apparently unaffected by wildfire.

Of 11 nonnative fish species examined, 8 experienced significant declines and 1 species increased in biomass after 1 or 2 fires. These changes were most pronounced after fire 1 at tributary 1 (cold water) and canyon 2 . Declines at tributary 1 after fire 1 resulted from the extirpation of rainbow trout Oncorhynchus mykiss and brown trout Salmo trutta (Fig. 6A, B, Table 3), which were the only nonnative fishes to occur at this site. Significant biomass decreases at canyon 2 after fire 1 occurred for Channel Catfish Ictalurus punctatus (99\%; 0.12 [0.00-0.26] to 0.0007 [0.00-0.01] g WM/m²), Flathead Catfish Pylodictis olivaris (67\%) (Fig. 6C), and Smallmouth Bass Micropterus dolomieu (85\%) (Fig. 6D). Red Shiner Cyprinella lutrensis biomass increased at canyon 2 after fire 1 , but this increase was only from $0.0004(0.00-0.0009)$ to 0.007 (0.005$0.009) \mathrm{g} \mathrm{WM} / \mathrm{m}^{2}$. The only other site to exhibit changes after fire 1 was tributary 2, which had a $94 \%$ decrease in biomass of $0.002(0.00-0.005)$ to $0.0001(0.00-0.0004) \mathrm{g} \mathrm{WM} / \mathrm{m}^{2}$ for Fathead Minnow Pimephales promelas. Changes in nonnative fish biomass were fewer after 2 fires, with Common Carp Cyprinus carpio and Green Sunfish Lepomis cyanellus decreasing by $99 \%$ and $100 \%$ (Fig. 6E, F), respectively, at canyon 2, and L. cyanellus decreasing by $100 \%$ at valley 1. Biomass of Yellow Bullhead Ameiurus natalis 

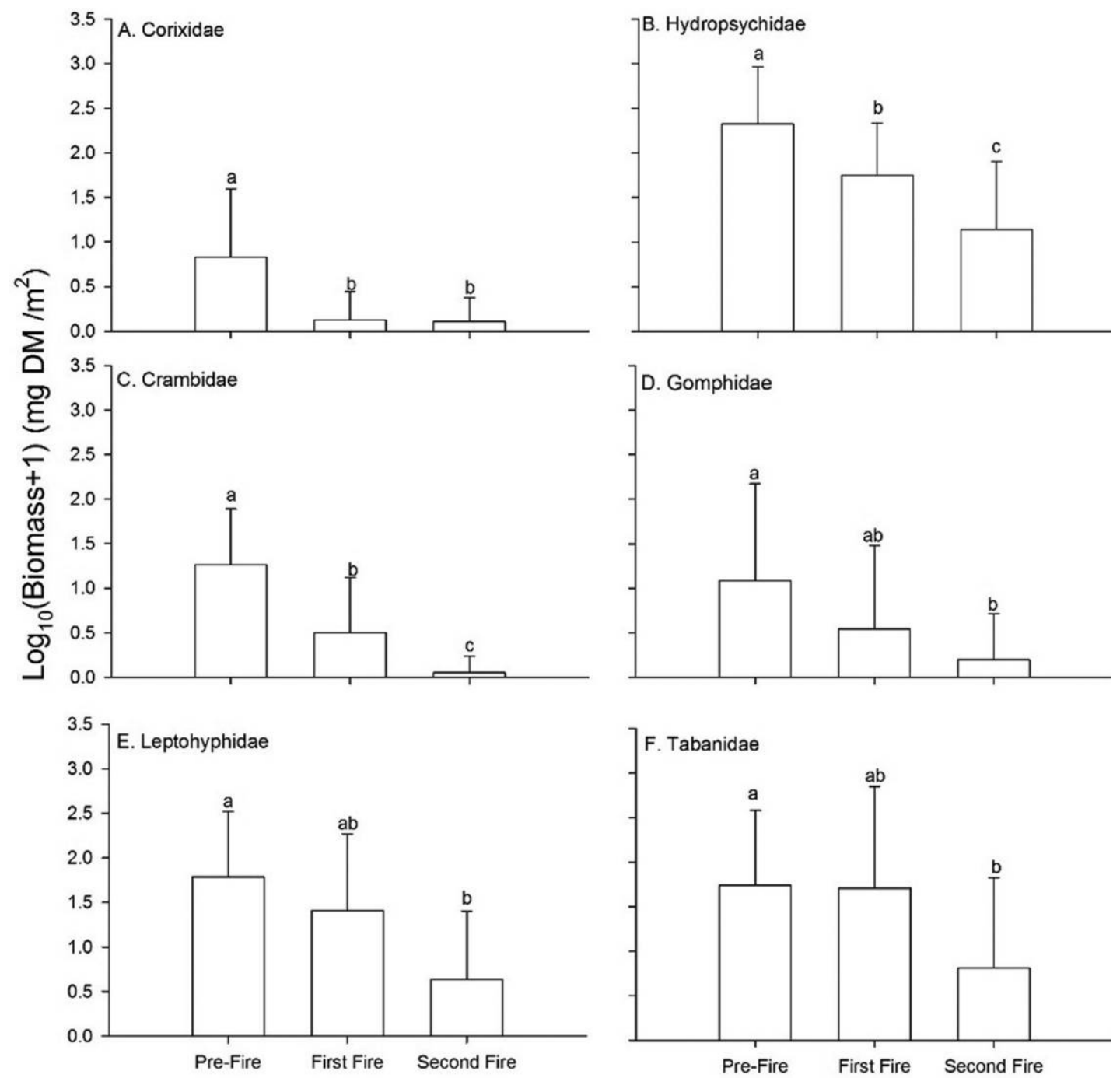

Figure 3. Mean (+1 SD) biomass of Corixidae (A), Hydropsychidae (B), Crambidae (C), Gomphidae (D), Leptohyphidae (E), and Tabanidae (F) before and after consecutive wildfires in the upper Gila River Basin, New Mexico, USA. See Table 3 for statistical results. Bars with the same letter are not significantly different. $\mathrm{DM}=$ dry mass.

and Western Mosquitofish Gambusia affinis did not change at any site following either fire.

\section{DISCUSSION}

\section{Abiotic and biotic responses to repeated wildfires}

Immediate abiotic and biotic responses to wildfire in the upper Gila River were more pronounced after the $2^{\text {nd }}$ fire than after the first. Greater changes following the $2^{\text {nd }}$ fire may have arisen because of cumulative effects of repeated wildfires, its larger size, concentration of ash flows because the $2^{\text {nd }}$ fire was followed by less precipitation than the $1^{\text {st }}$, or a combination of these factors. Cumulative effects are likely, given that wildfire perimeters were nonoverlapping and thus burned complementary areas, resulting in overall larger areas affected. Changes in habitat and basal resource availability were minimal after the $1^{\text {st }}$ fire but quite pronounced after the $2^{\text {nd }}$ fire. The monsoon season was weaker and produced lower-magnitude flows after the $2^{\text {nd }}$ than after the $1^{\text {st }}$ fire. Low-velocity flows that resulted from the weaker monsoon season would have allowed greater silt deposition from runoff originating from the burned area and explain the increase in silt observed at all sites after the $2^{\text {nd }}$ fire (Beschta and Jackson 1979, Wood and Armitage 1997). This increase in silt could explain the decrease in chlorophyll $a$ concentration after the $2^{\text {nd }}$ fire because silt deposition in rivers can decrease algal biomass via smothering (Yamada and Nakamura 2002, Izagirre et al. 2009). Increases in silt and decreases in algal biomass at all sites refuted our hypothesis of decreasing wildfire effects with increasing stream size and distance from wildfire, a result suggesting the scale of our study was finer than the extent of wildfire influence. 


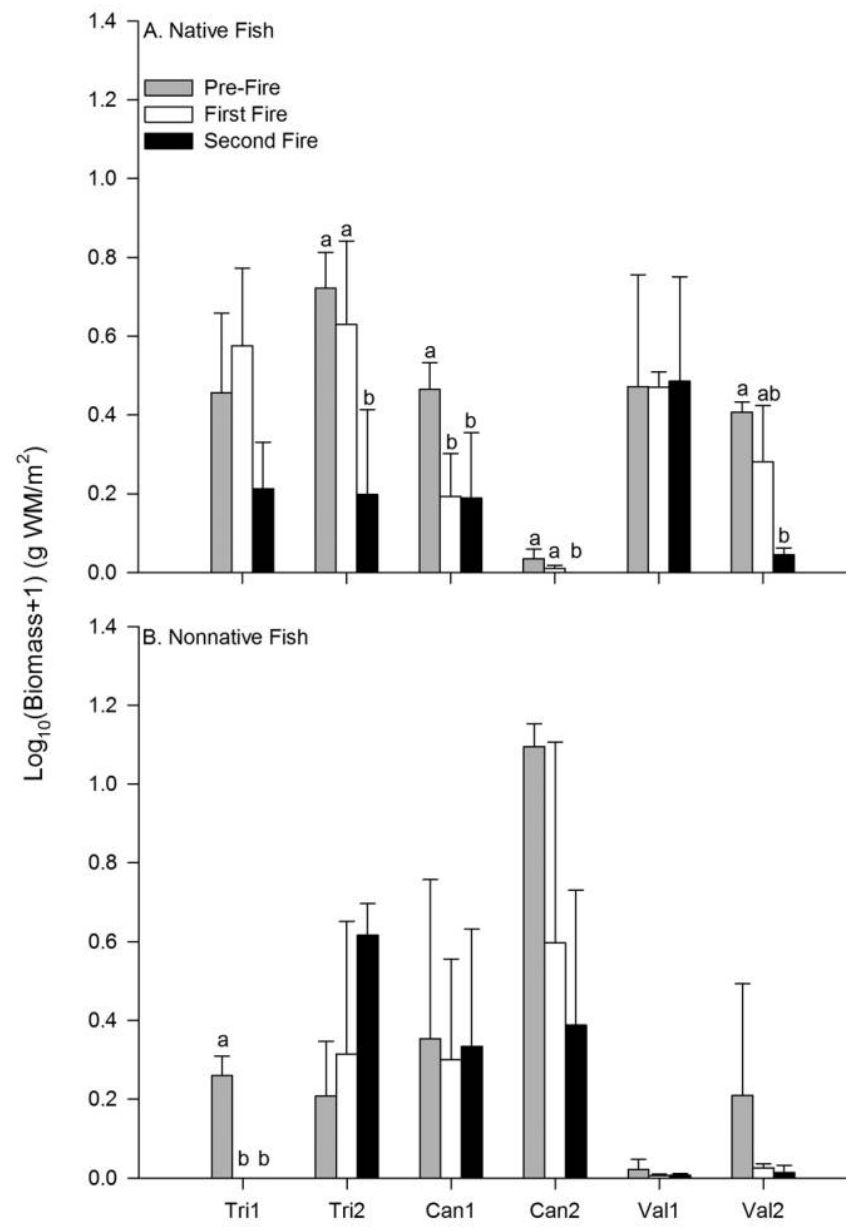

Figure 4. Mean $(+1 \mathrm{SD})$ biomass of native $(\mathrm{A})$ and nonnative (B) fishes before and after consecutive wildfires in the upper Gila River Basin, New Mexico, USA. See Table 3 for statistical results. Letters denote significant differences among time periods within sites, not among sites. Bars with the same letter are not significantly different. Tri = tributary, Can = canyon, $\mathrm{Val}=$ valley, $\mathrm{WM}=$ wet mass.

Increases in silt and lower algal biomass after runoff from the $2^{\text {nd }}$ fire also may explain the more pronounced decreases in insect biomass after this fire. Decreases in insect biomass were uniform across sites, a finding that further refutes our hypothesis of attenuation of wildfire effects with distance and stream size. Infiltration of silt into the interstitial spaces of substrate decreases habitat suitability for many insects that prefer to live on the undersurfaces of rocks (Erman and Ligon 1988, Richards and Bacon 1994) and interferes with their respiration (Lemly 1982). The insect taxa (Hydropsychidae and Crambidae) that exhibited the largest declines after wildfires both reside on the undersurface of rocks. Thus, siltation was a likely cause of their declines. Algal and macroinvertebrate biomass are positively correlated in the upper Gila River (Whitney et al. 2014), so perturbations that decrease algal biomass would be expected to decrease insect biomass. In addition to lower autochthonous resource supplies, insects may be responding to decreased quantity and quality of allochthonous inputs, which wildfires affect by altering terrestrial vegetation (Mihuc and Minshall 1995). Lower insect biomass associated with changes in habitat and resource availability following runoff from burned areas are consistent with the conclusions by Gresswell (1999), who suggested that wildfire-induced decreases in habitat quality and basal resource availability have the most pronounced effects on macroinvertebrate abundance. Macroinvertebrate richness and abundance might have increased if wildfire had occurred without runoff and had increased basal food resources, as reported by Rugenski and Minshall (2014). Increases in macroinvertebrate taxa with rapid turnover or high dispersal also can occur following wildfire (Vieira et al. 2004), but we did not observe any increases in macroinvertebrate biomass. However, despite wildfire-induced habitat deterioration, biomass of several insect families did not decrease following wildfire, results suggesting high resistance to wildfire disturbance.

In contrast to lower trophic groups, decreases in fish biomass were not necessarily related to wildfire-induced habitat changes because decreases occurred after the $1^{\text {st }}$ fire. Results for fishes supported our hypothesis of attenuating wildfire effects because fishes at upper sites generally exhibited greater decreases after the $1^{\text {st }}$ fire (which was more proximal to upper sites), whereas fishes at lower sites exhibited greater decreases after the $2^{\text {nd }}$ fire (which was more proximal to lower sites). Native fishes also might have declined at upper sites after the $2^{\text {nd }}$ fire had the $1^{\text {st }}$ fire not occurred, but biomass of several natives may have been too low (i.e., near 0) to exhibit further statistical decreases. Regardless, these results suggest that site proximity influences wildfire effects on native fishes. Lyon and O'Connor (2008) found that the effects of a wildfire on fishes in the Buckland River, Australia, decreased with increasing distance from the fire. Fish declines in the Buckland River were ascribed mainly to hypoxia resulting from ash flows, the effects of which attenuated downstream as they became diluted by tributary inputs. Dissolved $\mathrm{O}_{2}$ was not measured during our study, but dead native fishes were found after ash flows from each fire, and the most hypoxiaintolerant taxa (coldwater nonnative salmonids) were extirpated from tributary 1 . These fish kills also may be related to other causes of toxic water chemistry generated by wildfires (e.g., $\mathrm{NH}_{4}{ }^{+}$, trace metals, or ferrocyanides) that attenuated downstream (Gresswell 1999). These spatial effects were patchy for both wildfires. Fewer native decreases were observed at tributary 1 and valley 1 despite large decreases at other nearby sites (tributary 2, valley 2). These contrasting responses within longitudinal zones suggested minimal influence of local catchment characteristics in mediating wildfire effects. Patchiness of wildfire effects is 


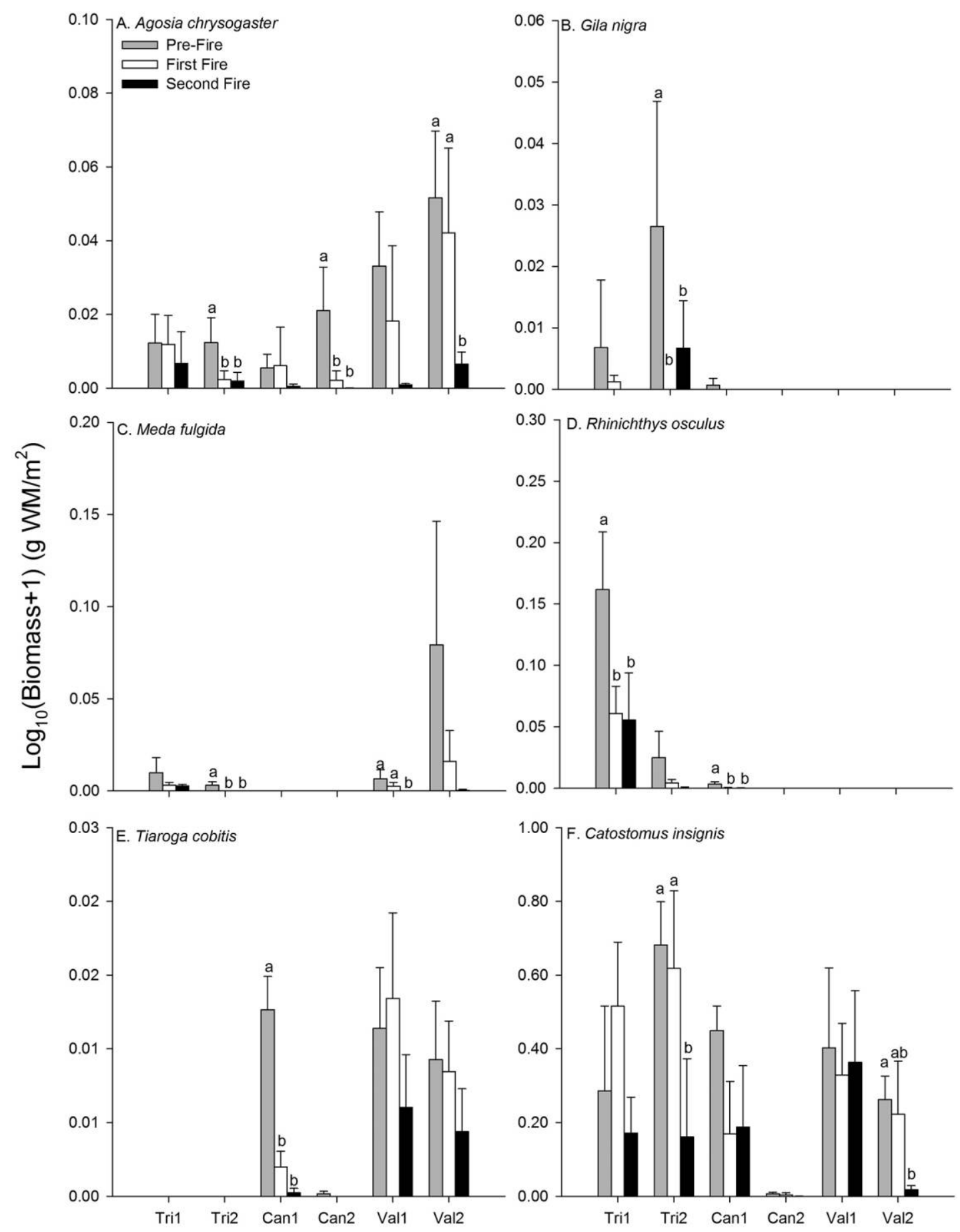

Figure 5. Mean (+1 SD) biomass of native fishes Agosia chrysogaster (A), Gila nigra (B), Meda fulgida (C), Rhinichthys osculus (D), Tiaroga cobitis (E), and Catostomus insignis (F) demonstrating significant site $\times$ time period responses to consecutive wildfires in the upper Gila River Basin, New Mexico, USA. See Table 3 for statistical results. Letters denote differences among time periods within sites, not among sites. Bars with the same letter are not significantly different. Tri = tributary, Can = canyon, Val = valley, WM = wet mass.

a common occurrence (Gresswell 1999) and may allow rapid recolonization of impacted sites because the Gila River is unfragmented and refuge sites are proximal to severely impacted sites.

\section{Interspecific variation in wildfire response}

Interspecific differences in response to wildfire were noted for native and nonnative fishes. For instance, $P$. clarkii was unaffected by either wildfire, whereas all other 

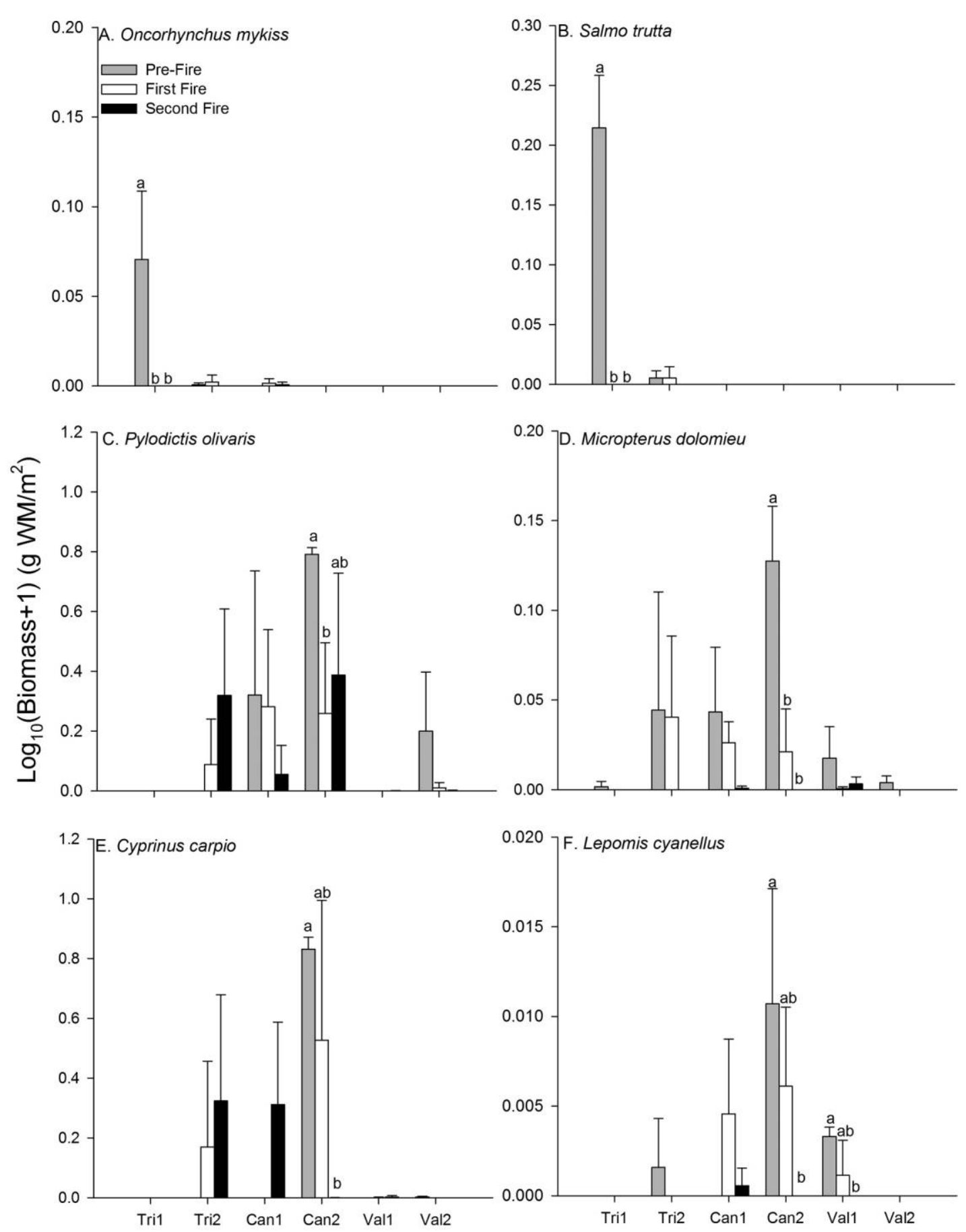

Figure 6. Mean (+1 SD) biomass of nonnative fishes Oncorhynchus mykiss (A), Salmo trutta (B), Pylodictis olivaris (C), Micropterus dolomieu (D), Cyprinus carpio (E), and Lepomis cyanellus (F) demonstrating significant site $\times$ time period responses to consecutive wildfires in the upper Gila River Basin, New Mexico, USA. See Table 3 for statistical results. Letters denote differences among time periods within sites, not among sites. Bars with the same letter are not significantly different. Tri $=$ tributary, Can $=$ canyon, $\mathrm{Val}=$ valley, $\mathrm{WM}=$ wet mass.

native fishes declined. Similarly, nonnative G. affinis and A. natalis biomass remained constant while other nonnative fishes (especially coldwater salmonids) declined. Drastic decreases and extirpations of native and nonnative salmonids following wildfires are well documented (Propst et al. 1992, Rinne 1996, Rieman et al. 2012), especially when ash flows occur (Bozek and Young 1994), and supports our hypothesis that coldwater species are more vulnerable than 
warmwater taxa to wildfire effects. Salmonids have among the lowest tolerances of hypoxic conditions of any freshwater fish, so their extirpation following hypoxic blackwater conditions is not surprising (Doudoroff and Shumway 1970, Gee et al. 1978). However, fish species' responses to wildfire also are likely to be influenced by variables other than dissolved $\mathrm{O}_{2}$, such as $\mathrm{NH}_{4}{ }^{+}$, trace metals, total suspended solids, and ferrocyanides (Bozek and Young 1994, Gresswell 1999). Differential susceptibility to wildfire probably is related to interspecific differences in traits, such as waterquality tolerance and microhabitat preference. Increased monitoring of postfire water quality coupled with experimental tests of among-species water-quality tolerances are needed to identify mechanisms conferring differential resistance to wildfire.

Despite subjection to consecutive wildfires, the biomass of nonnative $O$. virilis and $L$. catesbeianus remained stable throughout the study. These responses contradicted those observed for crayfish and tadpoles of different species occurring in their native ranges following wildfire. For example, the abundance of Murray crayfish Euastacus armatus was severely reduced ( $81 \%$ decrease) following a hypoxic blackwater event in the Murray River of Australia (McCarthy et al. 2014). This blackwater event was not caused by a wildfire, but the hypoxic conditions it produced were similar to those observed during a wildfireinduced ash flow on the Buckland River, Australia, that caused freshwater crayfish to exit the stream (Lyon and O'Connor 2008). Furthermore, densities of Rocky Mountain tailed frogs Ascaphus montanus in streams subjected to wildfire were only half of those in streams left unaffected (Hossack et al. 2006). These decreases in tadpole density were attributed to elevated temperature and $\mathrm{NH}_{4}{ }^{+}$ concentrations following wildfires. The high resistance to wildfire disturbance demonstrated by crayfish and tadpoles in our study compared with the lower resistance observed in other studies might be related to a suite of traits associated with differences in phylogeny. However, these results also hint that some nonnatives may be more tolerant than are native species of wildfire-induced disturbance, thus explaining nonnatives' ability to successfully invade habitats (Kolar and Lodge 2001, Marchetti et al. 2004). The limited effect on L. catesbeianus may be a consequence of the ability of terrestrial adults to withstand poor water quality and to re-invade rapidly once conditions improve. Similarly, resistance of nonnative O. virilis to ash flows may be related to the ability of crayfish to exit streams during harsh physicochemical conditions (Lyon and O'Connor 2008). Once outside the stream, crayfish can move to refuge aquatic habitats with less severe abiotic conditions (Grote 1981, Claussen et al. 2000) or could live terrestrially for several days (Pond 1975) and then re-enter the water once conditions improve. The lack of flushing flows during monsoons after either wildfire makes amphibious capabilities a viable mechanism promoting persistence.

Dunham et al. (2003) hypothesized that native and nonnative fishes possess differential susceptibility to wildfire disturbance in streams of western North America because of differences in wildfire-resistance traits conferred through evolutionary history with wildfire or otherwise. Our hypothesis that native fishes are less susceptible to effects of wildfire because of evolutionary history with wildfire was rejected because a larger proportion of native than nonnative fish species declined at a larger proportion of sites. Low resistance to wildfire disturbance is consistent with previous findings for natives, but high resistance exhibited by warmwater nonnatives contradicts the low resistance reported for coldwater nonnatives elsewhere (Sestrich et al. 2011). Pronounced native decreases may have arisen because postwildfire disturbances produced by contemporary megafires are more severe than historical wildfires (Dietrich 1983, Swetnam 1990). Limited nonnative responses to wildfires may be related to evolutionary histories with environmental conditions similar to but not necessarily caused by wildfire, such as tolerance of hypoxia, resource limitation, hyperturbidity, and flooding. The traits that conferred nonnative resistance to wildfire disturbance may be related to or the reason for their successful invasion (Moyle and Light 1996).

\section{Flow-regime consideration}

Wildfire appears to be a plausible factor for temporal changes observed in macroinvertebrate and macroconsumer biomass. However, the cumulative effects of successive years of drought also may cause changes. For instance, native fish richness and abundance has declined in response to consecutive years of drought in the upper Gila River, a pattern attributed to lower spawning success and greater predation pressure by nonnative piscivores (Propst et al. 2008). Drought might partly explain observed declines in native fishes, but drought and wildfire are inextricably linked (Schullery 1989, Swetnam and Betancourt 1998) and, thus, require a before-after-control-impact (BACI) design to disentangle effects of each. However, the large size and position of wildfires during our study eliminated this option because no suitable control sites with prefire data within the Gila River catchment were left unaffected by wildfire. Regardless, several lines of evidence point to wildfire effects on stream biota, including: 1) the spatial pattern of native fish declines (upper sites decreased following fire 1, lower sites decreased following fire 2), 2) the punctuated rather than gradual nature of macroinvertebrate and fish declines, 3) habitat-associated decreases in macroinvertebrate biomass, and 4) native fishes decreases at locations (tributary 1, valley 1 and 2) where nonnative piscivores were rare (Whitney et al. 2014). 


\section{Conclusions}

To the best of our knowledge, our study is the first in which responses of both cold- and warmwater native and nonnative taxa to large, consecutive wildfires were documented. Our results suggest that climate-related increases in wildfire frequency, size, and intensity will have negative consequences for native fishes, coldwater salmonids, and some native insects, while leaving native oligochaetes, nonnative crayfish, tadpoles, and many warmwater nonnative fishes less affected. We documented immediate responses, but continued monitoring will be crucial in assessing how large or repeated wildfires influence the trajectory of ecosystem recovery, especially in terms of native and nonnative abundance. Will lower susceptibility of nonnatives to wildfire ultimately increase their dominance in the community? Furthermore, interspecific differences in susceptibility to wildfire are in need of additional investigation because the traits responsible for wildfire susceptibility might be useful for identifying mechanisms of decline and creating species-specific management strategies. Our results suggest that increased extent, frequency, and scale of wildfire caused by historical fire suppression and ongoing climate change probably represent additional threats to the persistence of native fauna in the American Southwest and elsewhere. Aquatic biota are already highly imperiled as a result of dewatering, nonnative species, and range fragmentation (Miller 1961, Minckley and Deacon 1991, Olden and Poff 2005, Dudgeon et al. 2006), and additional pressures will only increase the need to implement rangewide conservation strategies. Native fauna would benefit from management activities that decrease fire size and severity (forest thinning and prescribed burning), but these activities carry their own set of concerns regarding forest management (Bisson et al. 2003, Rieman et al. 2010) and consequences for native fauna (Rieman and Clayton 1997). Activities that maintain or enhance the inherent resilience of ecosystems, such as nonnative removal (Propst et al. 2014) and maintenance or restoration of connectivity and habitat (Fagan 2002) are essential for ensuring native fauna persistence under a changing fire regime.

\section{ACKNOWLEDGEMENTS}

We thank M. Cooper of The Nature Conservancy for providing lodging at the Lichty Center and study site access at canyon 2 and valley 1, the US Forest Service for providing access at all other study sites, and K. Patten and A. Monie of the New Mexico Department of Game and Fish for providing logistical support and lodging at the Heart Bar Wildlife Management Area. This work would not have been completed without the help of numerous associates, especially K. Kirkbride, S. Hedden, J. Maine, E. Martin, J. Perkin, J. Rogosch, and M. Troia. We also thank M. Troia for assistance in making Fig. 1 and J. Whittier for help in calculating watershed and burned area. Earlier versions of this manuscript benefited from insightful comments by J. Du,
M. Mather, B. Sandercock, Guest Editor Lee Brown, and 3 anonymous referees. This research was supported by the Bureau of Reclamation and US Fish and Wildlife Service Desert Landscape Conservation Cooperative, a New Mexico Department of Game and Fish and US Fish and Wildlife Service State Wildlife Grant, and a Department of Education Graduate Assistance in Areas of National Need PhD Fellowship. Sampling was conducted under US Fish and Wildlife Services permit TE067729-3, New Mexico Game and Fish permit \#3351, and Kansas State University IACUC protocol 3296.

\section{LITERATURE CITED}

Benda, L., D. Miller, P. Bigelow, and K. Andrus. 2003. The effects of post-fire erosion on channel environments, Boise River, Idaho. Forest Ecology and Management 178:105-119.

Benke, A. C., A. D. Huryn, L. A. Smock, and J. B. Wallace. 1999. Length-mass relationships for freshwater macroinvertebrates in North America with particular reference to the southeastern United States. Journal of the North American Benthological Society 18:308-343.

Beschta, R. L., and W. L. Jackson. 1979. The intrusion of fine sediment into a stable gravel bed. Journal of the Fisheries Research Board of Canada 36:204-210.

Bisson, P. A., B. E. Rieman, C. Luce, P. F. Hessburg, D. C. Lee, J. L. Kershner, G. H. Reeves, and R. E. Gresswell. 2003. Fire and aquatic ecosystems of the western USA: current knowledge and key questions. Forest Ecology and Management 178: 213-229.

Bonada, N., M. Rieradevall, and N. Prat. 2007. Macroinvertebrate community structure and biological traits related to flow permanence in a Mediterranean river network. Hydrobiologia 589:91-106.

Bowman, D. M., J. K. Balch, P. Artaxo, W. J. Bond, J. M. Carlson, M. A. Cochrane, C. M. D'Antonio, R. S. Defries, J. C. Doyle, S. P. Harrison, F. H. Johnston, J. E. Keeley, M. A. Krawchuk, C. A. Kull, J. B. Marston, M. A. Moritz, I. C. Prentice, C. I. Roos, A. C. Scott, T. W. Swetnam, G. R. van der Werf, and S. J. Pyne. 2009. Fire in the Earth system. Science 324:481-484.

Bozek, M. A., and M. K. Young. 1994. Fish mortality resulting from delayed effects of fire in the Greater Yellowstone Ecosystem. Great Basin Naturalist 54:91-95.

Brown, J. K. 1990. Effects of fire on streams. Pages 106-110 in F. Richardson and R. H. Hamre (editors). Wild Trout IV: Proceedings of the Symposium. Trout Unlimited, Arlington, Virginia.

Brown, T. J., B. L. Hall, and A. L. Westerling. 2004. The impact of twenty-first century climate change on wildland fire danger in the western United States: an applications perspective. Climatic Change 62:365-388.

Burgherr, P., and E. I. Meyer. 1997. Regression analysis of linear body dimensions vs. dry mass in stream macroinvertebrates. Archiv für Hydrobiologie 139:101-112.

Burton, T. A. 2005. Fish and stream habitat risks from uncharacteristic wildfire: observations from 17 years of fire-related disturbances on the Boise National Forest, Idaho. Forest Ecology and Management 211:140-149. 
Claussen, D. L., R. A. Hopper, and A. M. Sanker. 2000. The effects of temperature, body size, and hydration state on the terrestrial locomotion of the crayfish Orconectes rusticus. Journal of Crustacean Biology 20:218-223.

Covington, W. W., R. L. Everett, R. Steele, L. L. Irwin, T. A. Daer, and A. N. D. Auclair. 1994. Historical and anticipated changes in forest ecosystems of the Inland West of the United States. Pages 13-63 in R. N. Sampson and D. L. Adams (editors). Assessing forest ecosystem health in the Inland West. The Haworth Press, New York.

Cushing, C. E., and P. A. Olson. 1963. Effects of weed burning on stream conditions. Transactions of the American Fisheries Society 92:303-305.

Dietrich, J. H. 1983. Fire history of southwestern mixed conifer: a case study. Forest Ecology and Management 6:13-31.

Doudoroff, P., and D. L. Shumway. 1970. Dissolved oxygen requirements of freshwater fishes. Technical Paper 86. Food and Agriculture Organization of the United Nations, Rome, Italy.

Dudgeon, D., A. H. Arthington, M. O. Gessner, Z.-I. Kawabata, D. J. Knowler, C. Lévêque, R. J. Naiman, A.-H. PrieurRichard, D. Soto, M. L. J. Stiassny, and C. A. Sullivan. 2006. Freshwater biodiversity: importance, threats, status and conservation challenges. Biological Reviews 81:163-182.

Dunham, J. B., A. E. Rosenberger, C. H. Luce, and B. E. Rieman. 2007. Influences of wildfire and channel reorganization on spatial and temporal variation in stream temperature and the distribution of fish and amphibians. Ecosystems 10:335-346.

Dunham, J. B., M. K. Young, R. E. Gresswell, and B. E. Rieman. 2003. Effects of fire on fish populations: landscape perspectives on persistence of native fishes and nonnative fish invasions. Forest Ecology and Management 178:183-196.

Earl, S. R., and D. W. Blinn. 2003. Effects of wildfire ash on water chemistry and biota in South-Western U.S.A. streams. Freshwater Biology 48:1015-1030.

Erman, D. C., and F. K. Ligon. 1988. Effects of discharge fluctuation and the addition of fine sediment on stream fish and macroinvertebrates below a water-filtration facility. Environmental Management 12:85-97.

Fagan, W. F. 2002. Connectivity, fragmentation, and extinction risk in dendritic metapopulations. Ecology 83: 3243-3249.

Gee, J. H., R. F. Tallman, and H. J. Smart. 1978. Reactions of some Great Plains fishes to progressive hypoxia. Canadian Journal of Zoology 56:1962-1966.

Gido, K. B., D. L. Propst, J. D. Olden, and K. R. Bestgen. 2013. Multidecadal responses of native and introduced fishes to natural and altered flow regimes in the American Southwest. Canadian Journal of Fisheries and Aquatic Sciences 70:554564.

Gresswell, R. E. 1999. Fire and aquatic ecosystems in forested biomes of North America. Transactions of the American Fisheries Society 128: 193-221.

Grote, J. R. 1981. The effect of load on locomotion in crayfish. Journal of Experimental Biology 92:277-288.

Hall, J. D., and R. L. Lantz. 1969. Effects of logging on the habitat of coho salmon and cutthroat trout in coastal streams. Pages 335-375 in T. G. Northcote (editor). Symposium on Salmon and Trout in streams. MacMillan Lectures in Fisheries, University of British Columbia, Vancouver.
Hessburg, P. F., and J. K. Agee. 2003. An environmental narrative of inland northwest US forests, 1800-2000. Forest Ecology and Management 178:23-59.

Hitt, N. P. 2003. Immediate effects of wildfire on stream temperatures. Journal of Freshwater Ecology 18:171-173.

Hossack, B. R., P. S. Corn, and D. B. Fagre. 2006. Divergent patterns of abundance and age-class structure of headwater stream tadpoles in burned and unburned watersheds. Canadian Journal of Zoology 84:1482-1488.

Howell, P. J. 2006. Effects of wildfire and subsequent hydrologic events on fish distribution and abundance in tributaries of North Fork John Day River. North American Journal of Fisheries Management 26:983-994.

Hurteau, M. D., J. B., Bradford, P. Z. Fulé, A. H. Taylor, and K. L. Martin. 2014. Climate change, fire management, and ecological services in the southwestern US. Forest Ecology and Management 327:280-289.

Izagirre, O., A. Serra, H. Guasch, and A. Elosegi. 2009. Effects of sediment deposition on periphyton biomass, photosynthetic activity and algal community structure. Science of the Total Environment 407:5694-5700.

Kolar, C. S., and D. M. Lodge. 2001. Progress in invasion biology: predicting invaders. Trends in Ecology and Evolution 16:199204.

Legleiter, C. J., R. L. Lawrence, M. A. Fonstad, W. A. Marcus, and R. Aspinall. 2002. Fluvial response a decade after wildfire in the northern Yellowstone ecosystem: a spatially explicit analysis. Geomorphology 1304:1-18.

Lemly, A. D. 1982. Modification of benthic insect communities in polluted streams: combined effects of sedimentation and nutrient enrichment. Hydrobiologia 87:229-245.

Lyon, J. P., and J. P. O'Connor. 2008. Smoke on the water: can riverine fish populations recover following a catastrophic firerelated sediment slug? Austral Ecology 33:794-806.

Lyons, J., L. Wang, and T. D. Simson. 1996. Development and validation of an index of biotic integrity for coldwater streams in Wisconsin. North American Journal of Fisheries Management 16:241-256.

Malison, R. L., and C. V. Baxter. 2010. The fire pulse: wildfire stimulates flux of aquatic prey to terrestrial habitats driving increases in riparian consumers. Canadian Journal of Fisheries and Aquatic Sciences 67:570-579.

Marchetti, M. P., P. B. Moyle, and R. Levine. 2004. Alien fishes in California watersheds: characteristics of successful and failed invaders. Ecological Applications 14:587-596.

May, C. L., and R. E. Gresswell. 2003. Processes and rates of sediment and wood accumulation in headwater streams of the central Oregon Coast Range. Earth Surface Processes and Landforms 28:409-424.

McCarthy, B., S. Zukowski, N. Whiterod, L. Vilizzi, L. Beesley, and A. King. 2014. Hypoxic blackwater event severely impacts Murray crayfish (Euastacus armatus) populations in the Murray River, Australia. Austral Ecology 39:491-500.

McKenzie, D., Z. Gedalof, D. L. Peterson, and P. Mote. 2004. Climatic change, wildfire and conservation. Conservation Biology 18:890-902.

Merritt, R. W., K. W. Cummins, and M. B. Berg (editors). 2008. An introduction to the aquatic insects of North America. Kendall Hunt, Dubuque, Iowa. 
Mihuc, T. B., and G. W. Minshall. 1995. Trophic generalists vs. trophic specialists: implications for food web dynamics in post-fire streams. Ecology 76:2361-2372.

Miller, R. R. 1961. Man and the changing fish fauna of the American Southwest. Michigan Academy of Science and Arts Letters 46:365-404.

Minckley, W. L., and J. E. Deacon. 1991. Battle against extinction: native fish management in the American west. University of Arizona Press, Tucson, Arizona.

Minshall, G. W., J. T. Brock, and J. D. Varley. 1989. Wildfires and Yellowstone's stream ecosystems. BioScience 39:707-715.

Moody, E. K., and C. A. Taylor. 2012. Red swamp crayfish (Procambarus clarkii) discovered in the San Pedro River, Arizona: a new invader in a threatened ecosystem. Southwestern Naturalist 57:343-344.

Moritz, M. A., M. A. Parisien, E. Batllori, M. A. Krawchuck, J. Van Dorn, D. J. Ganz, and K. Hayhoe. 2012. Climate change and disruptions to global fire activity. Ecosphere 3:1-22.

Moyle, P. B., and T. Light. 1996. Biological invasions of fresh water: empirical rules and assembly theory. Biological Conservation 78:149-161.

Niemi, G. J., P. DeVore, N. Detenbeck, D. Taylor, J. D. Yount, A. Lima, J. Pastor, and R. J. Naiman. 1990. An overview of case studies on recovery of aquatic systems from disturbance. Environmental Management 14:571-587.

Olden, J. D. and N. L. Poff. 2005. Long-term trends of native and non-native fish faunas in the American Southwest. Animal Biodiversity and Conservation 28:75-89.

Olden, J. D., N. L. Poff, and K. R. Bestgen. 2006. Life-history strategies predict fish invasions and extirpations in the Colorado River basin. Ecological Monographs 76:25-40.

Parisien, M.-A., and M. A. Moritz. 2009. Environmental controls on the distribution of wildfire at multiple spatial scales. Ecological Monographs 79:127-154.

Pausas, J., and J. Keeley. 2009. A burning story: the role of fire in the history of life. BioScience 59:593-601.

Pilger, T. J., K. B. Gido, and D. L. Propst. 2010. Diet and trophic niche overlap of native and nonnative fishes in the Gila River, USA: implications for native fish conservation. Ecology of Freshwater Fish 19:300-321.

Pond, C. M. 1975. The role of 'walking legs' in aquatic and terrestrial locomotion of the crayfish Austropotamobius pallipes (Lereboullet). Journal of Experimental Biology 62:447-454.

Propst, D. L., K. B. Gido, and J. A. Stefferud. 2008. Natural flow regimes, nonnative fishes, and native fish persistence in aridland river systems. Ecological Applications 18:1236-1252.

Propst, D. L., K. B. Gido, J. E. Whitney, E. I. Gilbert, T. J. Pilger, A. M. Monié, Y. M. Paroz, J. M. Wick, J. A. Monzingo, and D. M. Myers. 2014. Efficacy of removing nonnative predators from a desert stream. River Research and Applications. doi:10.1002/rra.2768

Propst, D. L., J. A. Stefferud, and P. R. Turner. 1992. Conservation and status of Gila trout, Oncorhynchus gilae. Southwestern Naturalist 37:117-125.

Quinn, T. P. 2005. The behavior and ecology of Pacific salmon and trout. University of Washington Press, Seattle, Washington.

Richards, C., and K. L. Bacon. 1994. Influence of fine sediment on macroinvertebrate colonization of surface and hyporheic stream substrates. Great Basin Naturalist 54:106-113.
Richter, A., and S. A. Kolmes. 2005. Maximum temperature limits for Chinook, coho, and chum salmon, and steelhead trout in the Pacific Northwest. Reviews in Fisheries Science 13:23-49.

Rieman, B. E., and J. Clayton. 1997. Wildfire and native fish: issues of forest health and conservation of sensitive species. Fisheries 22(11):6-15.

Rieman, B. E., and J. B. Dunham. 2000. Metapopulations and salmonids: a synthesis of life history patterns and empirical observations. Ecology of Freshwater Fish 9:51-64.

Rieman, B., R. Gresswell, and J. Rinne. 2012. Fire and fish: a synthesis of observation and experience. Pages 159-175 in C. Luce, P. Morgan, K. Dwire, D. Isaak, Z. Holden, and B. Rieman (editors). Climate change, forests, fire, water, and fish: building resilient landscapes, streams, and managers. General Technical Report RMRS-GTR-290. Rocky Mountain Research Station, US Department of Agriculture Forest Service, Fort Collins, Colorado.

Rieman, B. E., P. F. Hessburg, C. Luce, and M. R. Dare. 2010. Wildfire and management of forests and native fishes: conflict or opportunity for convergent solutions? BioScience 60: 460-468.

Rieman, B., D. Lee, D. Burns, R. Gresswell, M. Young, R. Stowell, J. Rinne, and P. Howell. 2003. Status of native fishes in the western United States and issues for fire and fuels management. Forest Ecology and Management 178: 197-211.

Rieman, B., D. Lee, G. Chandler, and D. Myers. 1995. Does wildfire threaten extinction for salmonids? Responses of redband trout and bull trout following recent large fires on the Boise National Forest. Pages 47-57 in Proceedings-Fire Effects on Rare and Endangered Species and Habitats Conference. International Association of Wildland Fire, Coeur d' Alene, Idaho.

Rinne, J. N. 1996. Short-term effects of wildfire on fishes and aquatic macroinvertebrates in the southwestern United States. North American Journal of Fisheries Management 16:653-658.

Rosenberger, A. E., J. B. Dunham, J. M. Buffington, and M. S. Wipfli. 2011. Persistent effects of wildfire and debris flows on the invertebrate prey base of rainbow trout in Idaho streams. Northwest Science 85:55-63.

Rugenski, A. T., and G. W. Minshall. 2014. Climate-moderated responses to wildfire by macroinvertebrates and basal food resources in montane wilderness streams. Ecosphere 5:1-24.

Sabo, J. L., J. L. Bastow, and M. E. Power. 2002. Length-mass relationships for adult aquatic and terrestrial invertebrates in a California watershed. Journal of the North American Benthological Society 21:336-343.

Schullery, P. 1989. The fires and fire policy. BioScience 39:686694.

Sestrich, C. M., T. E. McMahon, and M. K. Young. 2011. Influence of fire on native and nonnative salmonid populations and habitat in a western Montana basin. Transactions of the American Fisheries Society 140:136-146.

Smale, M. A., and C. F. Rabeni. 1995. Hypoxia and hyperthermia tolerances of headwater stream fishes. Transactions of the American Fisheries Societv 124:698-710.

Spencer, C. N., and F. R. Hauer. 1991. Phosphorus and nitrogen dynamics in streams during a wildfire. Journal of the North American Benthological Society 10:24-30. 
Stefferud, J. A., K. B. Gido, and D. L. Propst. 2011. Spatially variable response of native fish assemblages to discharge, predators and habitat characteristics in an arid-land river. Freshwater Biology 56:1403-1416.

Steinman, A. D., G. A. Lamberti, and P. R. Leavitt. 2006. Biomass and pigments of benthic algae. Pages 357-379 in F. R. Hauer and G. A. Lamberti (editors). Methods in stream ecology. Academic Press, San Diego, California.

Stephens, S. L., N. Burrows, A. Buyantuyev, R. W. Gray, R. E. Keane, R. Kubian, S. Liu, F. Seijo, L. Shu, K. G. Tolhurst, and J. W. van Wagtendonk. 2014. Temperate and boreal megafires: characteristics and challenges. Frontiers in Ecology and the Environment 12:115-122.

Swetnam, T. W. 1990. Fire history and climate in the southwestern United States. Pages 6-17 in J. S. Krames (editor). Proceedings of Symposium on Effects of Fire in Management of Southwestern US Natural Resources. US Forest Service, Tucson, Arizona.

Swetnam, T. W., and J. L. Betancourt. 1998. Mesoscale disturbance and ecological response to decadal climatic variability in the American Southwest. Iournal of Climate 11:3128-3147.

Thorp, J. H., and A. P. Covich (editors). 2001. Ecology and classification of North American freshwater invertebrates. Academic Press, San Diego, California.

Verkaik, I., M. Rieradevall, S. C. Cooper, J. M. Melack, T. L. Dudley, and N. Prat. 2013. Fire as a disturbance in Mediterranean climate streams. Hydrobiologia 719:353-382.
Vieira, N. K. M., W. H. Clements, L. S. Guevara, and B. F. Jacobs. 2004. Resistance and resilience of stream insect communities to repeated hydrologic disturbances after a wildfire. Freshwater Biology 49:1243-1259.

Westerling, A. L., H. G. Hidalgo, D. R. Cayan, and T. W. Swetnam. 2006. Warming and earlier spring increases western US forest wildfire activity. Science 313:940-943.

Whitney, J. E., K. B. Gido, and D. L. Propst. 2014. Factors associated with the success of native and nonnative species in an unfragmented arid-land riverscape. Canadian Journal of Fisheries and Aquatic Sciences 71:1134-1145.

Wood, P. J., and P. D. Armitage. 1997. Biological effects of fine sediment in the lotic environment. Environmental Management 21:203-217.

Yamada, H., and F. Nakamura. 2002. Effects of fine sediment deposition and channel works on periphyton biomass in the Makomanai River, northern Japan. River Research and Applications 18:481-493.

Young, M. K. 2012. Aquatic species invasions in the context of fire and climate change. Pages 195-207 in C. Luce, P. Morgan, K. Dwire, D. Isaak, Z. Holden, and B. Rieman (editors). Climate change, forests, fire, water, and fish: building resilient landscapes, streams, and managers. General Technical Report RMRS-GTR-290. Rocky Mountain Research Station, US Department of Agriculture Forest Service, Fort Collins, Colorado. 